Original article

\title{
An overview of Mesopotamian bronze metallurgy during the 3rd millennium $\mathrm{BC}$
}

\author{
I. De Ryck ${ }^{a}$, A. Adriaens ${ }^{b}, *, F$. Adams ${ }^{a}$ \\ a Department of Chemistry, University of Antwerp, Campus Drie Eiken, Universiteitsplein 1, 2610 Antwerp, Belgium \\ ${ }^{\mathrm{b}}$ Department of Analytical Chemistry, Ghent University, Krijgslaan 281-S12, 9000 Ghent, Belgium
}

Received 1 September 2004; accepted 27 April 2005

\begin{abstract}
Literature results of chemical bronze analyses originating from Near Eastern excavation sites have been assembled to obtain a general overview of the Mesopotamian bronze technology during the 3rd millennium BC. Results show that at the end of the 4th and at the beginning of the 3rd millennium BC arsenic alloys with an arsenic concentration up to 5\% were generally into use, while tin bronzes were introduced during the middle of the 3rd millennium. This introduction appears almost synchronously over the entire region of Mesopotamia, although there is an indication that the tin bronze introduction was slightly later in southern Mesopotamia.
\end{abstract}

(C) 2005 Elsevier SAS. All rights reserved.

Keywords: Mesopotamia; Metallurgy; Bronze; Third millennium BC

\section{Introduction}

The use of copper goes back in time at least 10,000 years: the first evidence for human exploitation of native copper deposits comes from the Neolithic site of Cayonü Tepesi in south-eastern Turkey, where beads of malachite and native copper were found that date back 7250-6750 BC [1]. In addition, small objects made of copper, such as pins and awls were found sporadically in very early contexts around the 9th-7th millennia BC, e.g. at Ali Kosh in Western Iran, and Cayönü Tepesi near Ergani in Anatolia [2].

Examination of artefacts made of native copper show that they were usually fabricated by hammering, followed by annealing at high temperature. Heating to about $1100{ }^{\circ} \mathrm{C}$ would have melted the metal and thus initiated the casting of metal as a shaping method. Such high temperatures are easily feasible in a charcoal fire. The discovery of melting metal almost certainly led to the discovery of the technology of smelting [3]. Unfortunately, the distinction between melted native copper and copper smelted from pure ores is very hard or even impossible to make, which means that it is difficult to find out when copper ores were first smelted [4].

\footnotetext{
* Corresponding author. Tel.: +32 9264 4826; fax: +329264 4960.

E-mail address: Annemie.Adriaens@UGent.be (A. Adriaens).
}

It took until about the 4th millennium BC before metal production really started [3]. The first raw material used for copper smelting is undoubtedly provided by oxide zone copper deposits. Later in the Bronze Age, oxide deposits would have become depleted and copper sulphide ores must have become the main source of copper. The copper sulphide ore was found to be present underneath the oxide zones and in regions where erosion exposed the primary ores [5]. In Anatolia, Iran, Oman and Cyprus most of the copper deposits consist of sulphide ores. To produce copper from these sulphide ores, they must first have been roasted in an oxidising atmosphere in order to produce a copper oxide, after which the copper oxide reacted with the copper sulphide to produce copper and sulphur dioxide. If the initial process is incomplete an impure mixture of copper and copper sulphide is produced which is known as matte. This matte must be fully roasted to oxides and reduced with carbon to produce more or less pure copper. In practice, most early smelting of sulphide ores was probable aimed at a dead roast to oxide followed by a simple reduction with charcoal. The nature of a sulphide ore thus presupposes a two-stage smelting process, reduction of the raw ore to matte, followed by refining to a state in which the metal is pure enough to be used $[6,7]$.

During the 4 th millennium BC to the late Bronze Age, copper arsenic alloys were produced and used throughout the 


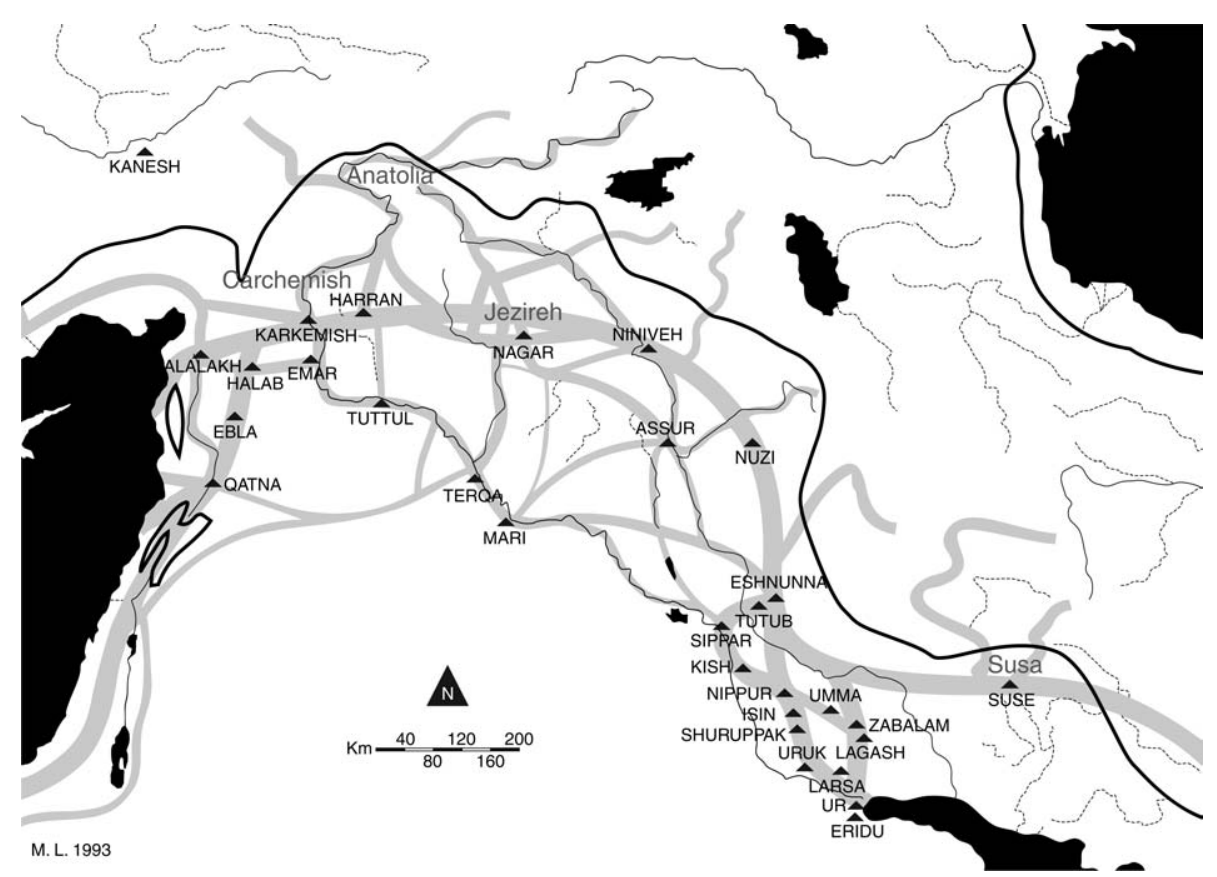

Fig. 1. Mesopotamia and Levant during the 3rd millennium BC. Main commercial land routes are indicated by thick grey lines [17].

Near East. It is only more than a millennium later that the development of copper tin alloys started. Around $1500 \mathrm{BC}$ the tin bronze replaced the copper arsenic alloy completely [8].

Recent reports on the production of copper arsenic alloys show a wide variety in arsenic concentration and demonstrate at the same time that it is impossible to recognise whether a certain concentration of arsenic indicates an intentionally created alloy [8-10]. Moreover, there is no agreement on whether or not the arsenical copper alloys were intentionally created. In contrast to the arsenical bronzes tin bronzes with a concentration of $2 \mathrm{wt} \%$ of tin indicate a deliberately created alloy [11]. However, lower figures down to $0.5 \mathrm{wt} \%$ have been reported as intentionally created alloys as well [12]. Nevertheless it is generally accepted that lower amounts of tin originate from the copper ore used, even though they can also be explained by the use of metal scrap containing tin $[2,10,13]$. Tin could enter the metal scrap because the spread of the tin bronzes was faster in the Near East than the spread of the technology related to tin bronzes [13]. Some sources even mention that objects with a tin content of $1-4 \mathrm{wt} . \%$ were probably not intentionally produced alloys but were the result of melting down tin bronze together with copper objects in order to cast new pieces [6].

Although it is generally accepted that most of the tin bronzes were intentionally created alloys, the origins of the tin ores in the ancient Near East remains until now a point of discussion. Based on the geological environment, it is possible that tin was exploited in Iran, although there is no concrete evidence for any mining activities. In Afghanistan, on the other hand, there is evidence of the exploitation of tin. It is supposed that the tin from this region was imported into Mesopotamia through the existing trading network of lapis lazuli and gold [10]. At Kestel in Anatolia (Turkey) a mining complex which is believed to be a mine of tin of the Bronze Age was discovered [14]. Additionally an early Bronze Age mining village, Göltepe, was discovered nearby the entrance of the Kestel mine in 1988. At both sites numerous crucible shreds with a tin rich residue have been found [15]. Other sources of tin exist elsewhere in Turkey [16]. From these literature data it is clear that there are many possible sources of tin, however it remains unclear which region was the most important tin supplier for the production of Mesopotamian bronzes.

In this work literature results of chemical bronze analyses originating from Near Eastern excavation sites have been assembled to obtain a general overview of the Mesopotamian bronze technology during the 3rd millennium BC. Mesopotamia refers in the first instance to the land between the rivers Tigris and Euphrates, however, it can be more broadly defined to include also the area that is now Eastern Syria, Southeastern Turkey, and the rest of present Iraq (Fig. 1). This region was the centre of a culture whose influence extended throughout the Middle East and as far as the Indus valley, Egypt and the Mediterranean. In the Mesopotamian region Sumeria (later Summur and Akkad, after this Babylonia) and Assyria flourished. The best known Assyrian cities, all situated in the territory of present day Iraq, are Ashur, Nineveh and Calah (Nimrud). Table 1 gives a summary of the different periods of Mesopotamia mentioned in this work.

\section{The Jezireh region}

The Jezireh ("the isle") is situated between the upper arms of the rivers Tigris and Euphrates. Four sites will be considered in this area. 
Table 1

Chronology of periods in Mesopotamia [23]

\begin{tabular}{|c|c|c|c|}
\hline Proto-neolithic & Natufian/Khiamian & & $10,000-8500 \mathrm{BC}$ \\
\hline \multirow[t]{3}{*}{ Neolithic } & Pre-pottery neolithic & & $8500-6300 \mathrm{BC}$ \\
\hline & Hassuna/Samarra & & $6300-5250 \mathrm{BC}$ \\
\hline & Halaf & Susa I & $5250-4700 \mathrm{BC}$ \\
\hline \multirow[t]{2}{*}{ Chalcolithic } & Ubaid & & $4700-3700 \mathrm{BC}$ \\
\hline & Uruk & Susa II & $3700-3100 \mathrm{BC}$ \\
\hline Early Bronze Age I & Jemdet Nasr & Susa III & $3100-2950 \mathrm{BC}$ \\
\hline Early Bronze Age II & Early Dynastic I (EDI) & Susa IIIb & $2950-2700 \mathrm{BC}$ \\
\hline \multirow[t]{3}{*}{ Early Bronze Age III } & Early Dynastic II (EDII) & & $2700-2550 \mathrm{BC}$ \\
\hline & & Susa IVa & \\
\hline & Early Dynastic III (EDIII) & & $2550-2350 \mathrm{BC}$ \\
\hline Early Bronze Age IVa & Akkadian & Susa IVb & $2350-2200 \mathrm{BC}$ \\
\hline Early Bronze Age Ivb & Ur III & Susa V & $2100-2000 \mathrm{BC}$ \\
\hline Middle Bronze Age I-II & Amorite kings & & $2000-1600 \mathrm{BC}$ \\
\hline Middle Bronze Age II & Old Assyrian & & $1900-1600 \mathrm{BC}$ \\
\hline Late Bronze Age & Middle Assyrian & & $1370-1150 \mathrm{BC}$ \\
\hline \multirow[t]{2}{*}{ Iron Age I } & Invasion of sailors & & $1200-1100 \mathrm{BC}$ \\
\hline & First Aramaen realms & & $1100-950 \mathrm{BC}$ \\
\hline \multirow[t]{3}{*}{ Iron Age II } & Aramaean and & & $950-612 \mathrm{BC}$ \\
\hline & Neo-Assyrian & & \\
\hline & Neo-Babylonian & & $612-539 \mathrm{BC}$ \\
\hline \multirow[t]{2}{*}{ Iron Age III } & Persian & & $539-332 \mathrm{BC}$ \\
\hline & Hellinistic, Seleucidic and & & $332-50 \mathrm{BC}$ \\
\hline
\end{tabular}

\subsection{Tell Beydar}

In a study by De Ryck et al. [18], 46 bronze objects from the site Tell Beydar were investigated to assess their composition and microstructure. SEM-EDX data showed that the excavated copper alloys contain mainly arsenic and tin as major alloying elements. Four different compositional groups could be distinguished: a low arsenic content group (As $<2$ wt.\%), a high arsenic content group (As $>2$ wt.\%), an intermediate tin content group (tin between 3 and 5 wt.\%) and a high tin content group ( $\mathrm{Sn}>6 \mathrm{wt} . \%)$. A study of the chronology demonstrated that both high-arsenical bronzes as well as low-arsenical bronzes were used during the EDII period (2700-2600 BC). During the later EDIII period (26002300 BC), high-arsenical bronzes were replaced by tin bronzes. In addition results show that during this later period more extensive recycling of the metals took place. Finally during the Akkadian (2300-2200 BC) and later periods no high-arsenical bronzes and little or no tin bronzes were used at Tell Beydar, whereas low-arsenical bronzes were used during the entire time span studied. Fig. 2 shows a scatter plot of the arsenic vs. tin content in these samples, which clearly indicates the difference between the various periods.

The study of the microstructure revealed that, in general, the same basic working techniques were used during the period studied. Basically roughly shaped objects were formed by casting the liquid metal into a mould. The object was then hammered, both cold and hot, into shape after cooling down. Although it is clear that the same basic methods were used throughout the various periods, the evolution of the microstructure shows that metal smiths were gradually achieving better control over the process of cold and hot working of the metal. At the end of the development period the metal smith knew quite well how to create objects having the same composition but with different properties especially hardness [18].

\subsection{Tell Brak, Tell Mozan and Tell Leilan}

Compositional results of bronzes from the sites Tell Brak (19 samples), Tell Mozan (50 samples) and Tell Leilan (15 samples) have been put together. Only the results of Tell Brak have been published to date [19]. The others were kindly

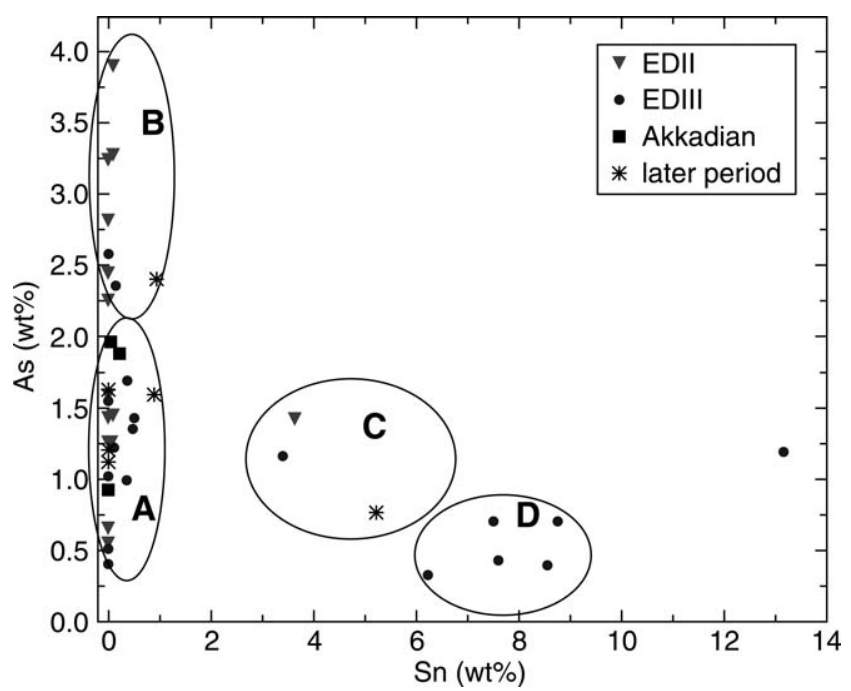

Fig. 2. Scatter plot of the arsenic vs. tin content measured by SEM-EDX for the Tell Beydar samples. (A) Low arsenic, (B) high arsenic, (C) low-tin, (D) high tin (with the copyright permission of Blackwell Publishers). 


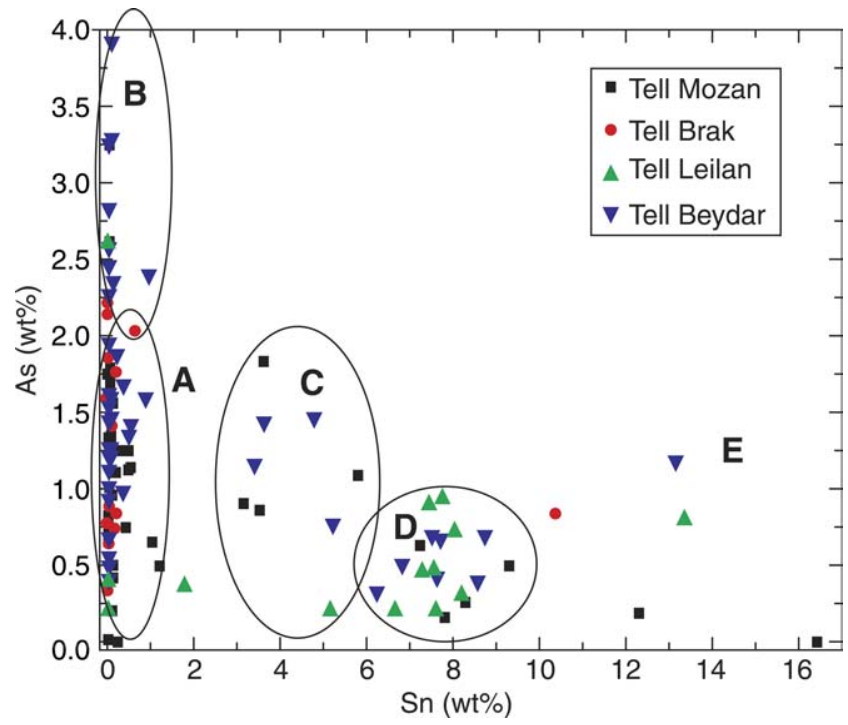

Fig. 3. Scatter plot of the arsenic vs. tin content for the Jezireh region. (A) Low and intermediate arsenic, (B) high arsenic, (C) low-tin, (D) intermediate tin, (E) high tin (data from [18] (Tell Beydar)) and kindly provided by P. Northover (Tell Mozan, Tell Brak and Tell Leilan).

provided by Dr. P. Northover, Oxford University. The majority of the samples from Tell Brak date to the Akkadian period. The samples of Tell Mozan are contemporary to the samples of Tell Beydar and the bronzes of Tell Leilan date to the 2nd millennium BC [20]. Those of Tell Mozan and Tell Leilan are not clearly dated, which eliminates the possibility of making a chronological sequence for the alloying elements used at these sites.

In general it can be concluded that for the Jezireh region mainly two types of copper alloys were used during the 3rd millennium BC, i.e. arsenic and tin containing alloys. The scatter plot of the arsenic vs. the tin concentration obtained from the entire set of data are shown in Fig. 3. High, intermediate and low concentrations of the main alloying element are observed for both the arsenical and the tin bronzes. The composition of the Jezireh bronzes shows similar compositional variations between sites, which is not surprising when the interdependence of the region on Tell Brak is considered. The absence of tin bronzes at Tell Brak during the Akkadian period indicates that in the Jezireh region the use of tin bronzes was generally ceased during this period, whereas the recovery of tin bronzes at Tell Leilan (2nd millennium BC) indicates that after this period tin bronze was commonly used again. Moreover, it appears that tin bronzes with an intermediate tin content (about $8 \mathrm{wt} . \%$ ) and a low arsenic concentration (about 0.5 wt. $\%$ ) were preferably used.

With regard to the provenance of the Jezireh bronzes, at least two different origins can be deduced based on the nickel content of the arsenical bronzes. This point of view is confirmed by differences in the silver content. However, for a better provenance study more accurate trace elemental analysis and/or lead isotope analysis would be helpful.

\section{The Carchemish region}

The Carchemish is located east from the Jezireh (Fig. 1). From this region, data of 98 bronze objects of the Wooley collection (Ashmolean museum, Oxford, UK) have been used in this study [21]. The majority of the bronzes date to the 3rd millennium BC. The absence of any exact dating again eliminates the possibility to draw any conclusions with regard to the chronological appearance of the bronzes. In spite of this, the metallurgical data are useful to compare with the results from the Jezireh region.

Fig. 4 shows that both arsenical and tin bronzes appear in the Carchemish region. The arsenic concentration of the arsenical bronzes is similar to that of the Jezireh bronzes, i.e. ranging from low (As < $0.5 \mathrm{wt} . \%$ ) to high (As > 2 wt. \%) concentrations. Compared to the Jezireh bronzes, similar variations in concentration are observed for the remaining elements, which means that: (1) efforts were made to increase the arsenic concentration of the high-arsenical bronzes; (2) recycling of bronzes occurred and (3) at least two different sources were used. In addition bronzes with a high nickel concentration (between 1 and 4 wt.\%) were discovered at the Carchemish, which means that an additional source of bronze or raw material was available in the region.

In the Carchemish region also the appearance of true tin bronzes is apparent. They can be divided into two groups: a group with an average tin concentration of about $4 \mathrm{wt}$.\% (lowtin) and a group with an average concentration of about $10 \mathrm{wt} \%$ (intermediate tin). Bronzes with a tin content above 12 wt.\% (high tin) are not observed. However, the subdivision into groups is not as easy as for the Jezireh bronzes. The intermediate tin bronzes of the region show a higher tin concentration than at the Jezireh (10 vs. $8 \mathrm{wt} \%$ ) which could imply that the tin bronzes of both regions originate from different locations.

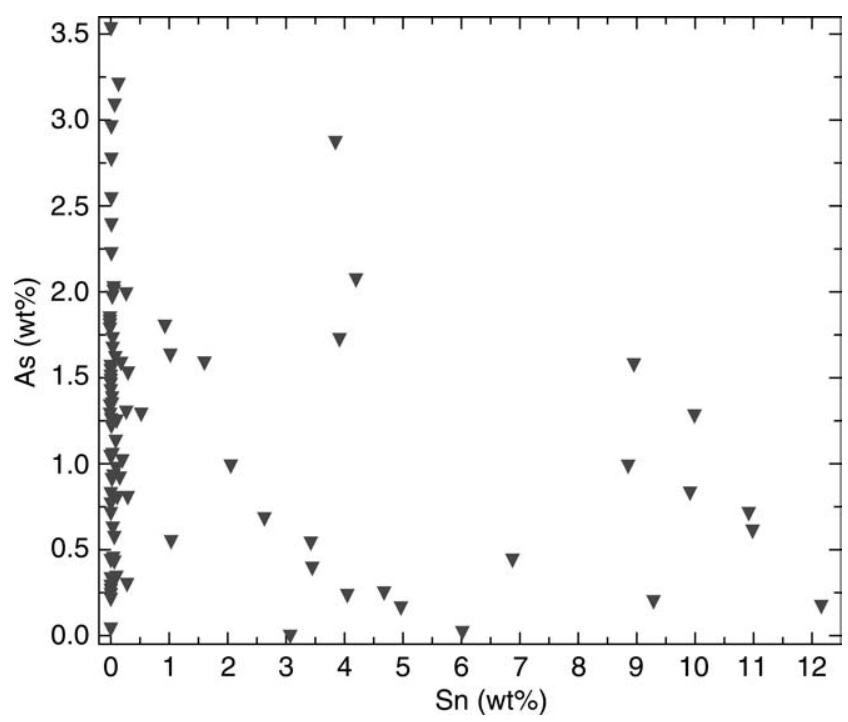

Fig. 4. Scatter plot of the arsenic vs. tin content for the Carchemish region (data from [21]). 


\section{Southern Mesopotamian sites}

\subsection{Susa}

Susa is located in southern Mesopotamia (present day Iran). A detailed description, including a compositional study, of bronzes of Susa has been published by Tallon and Malfoy [22]. Data (280 samples) used in this study are from Malfoy and Menu [23]. The arsenic and tin concentrations are shown in Fig. 5. The analysed bronzes date to the periods Susa I to Susa V of the 4th to 3rd millennium BC (Table 1).

Fig. 5 shows that intermediate arsenical bronzes were used during the entire time span, while bronzes with high arsenic content start to appear in period Susa II-IIIa. From this period on the majority of bronzes contain high and intermediate concentrations of arsenic until the end of period Susa IVa when the use of high-arsenical bronzes again decreases in favour to bronzes with low arsenic concentrations. This change in the use of arsenic as an alloying element coincides with the first appearance of true tin bronzes during period Susa IVa (Fig. 6). Bronzes with a high tin content start to appear in period Susa V.

Similar as for the Jezireh and Carchemish region it can be concluded that an effort was made to create bronzes with a high concentration of arsenic. The number of high-arsenical bronzes together with their average arsenic concentration decreases at the moment when tin bronzes start being produced. In addition, as in the Susa IVa period, the average concentration of tin as a minor constituent of the arsenical bronzes increases to an average concentration of about $0.1 \mathrm{wt} . \%$. This concentration change of tin at the moment when tin bronzes were introduced is an indication that metal scrap was used as a raw material for the bronze production [13]. Moreover the average iron content of the arsenical bronzes with a low concentration of arsenic ( $<0.5 \mathrm{wt} . \%)$ increases in the period Susa IVa, which possibly means that a change in metal technology

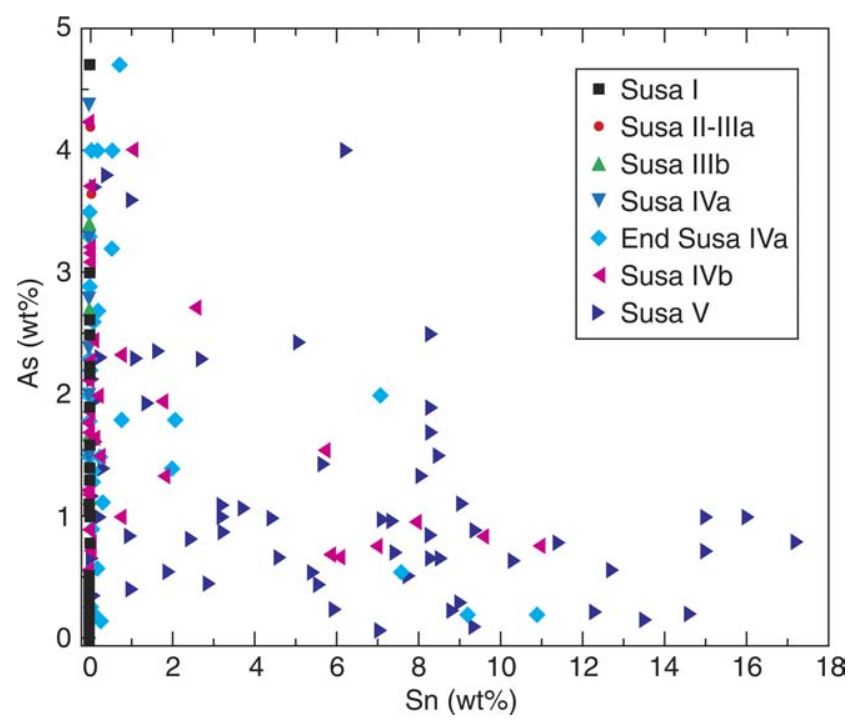

Fig. 5. Scatter plot of the arsenic vs. tin content for the samples from Susa (data from [23]).

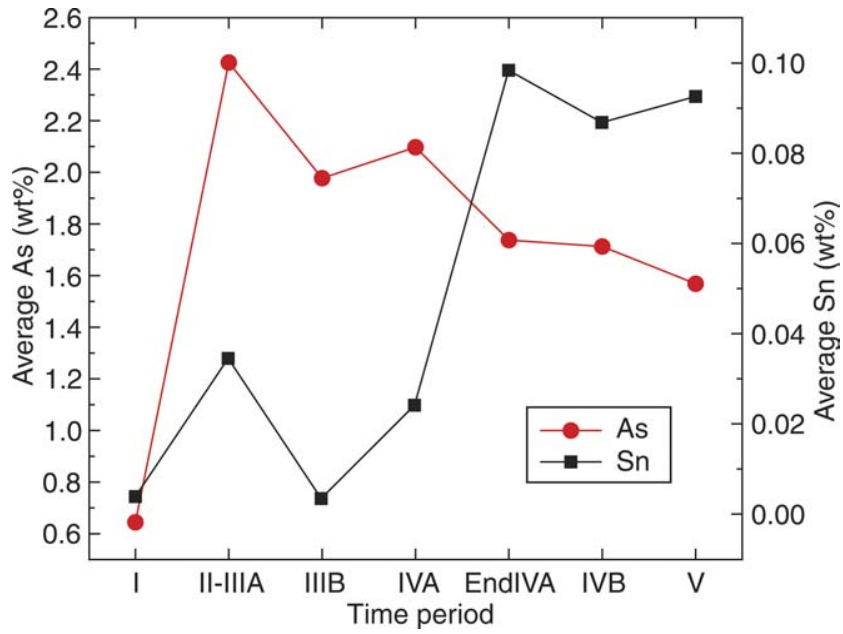

Fig. 6. Chronological evolution of the average arsenic and tin concentration of the arsenical bronzes in Susa (data from [23]).

took place in this period. Notable is that this change appears just before the introduction of tin bronze.

Obtaining information about the provenance of the bronzes from Susa is more difficult. Elements such as Ni, Sb, Ag, Co and $\mathrm{Bi}$, which can be related to the provenance of bronze, vary considerably over the time span studied. This could mean that depending on the period, different sources of bronze were available in Susa. Another explanation, however, could be that another type of ore was used over time such as e.g. sulphide ore instead of oxide ores. Furthermore extensive recycling and alloying of metals precludes the study of provenance through the trace element composition as they are mixed together.

\section{2. $U r$}

Data summarising of the composition of bronzes from other sites (Jedmet Nasr, Kish, Chagar Bazar, Serrin, Ur, Atshana) are published by Moorey [11]. Unfortunately, most of these metals were only analysed for their arsenic and tin content. Also in many cases no clear dating of the objects is available. This makes that the majority of the data are not useful for comparison with the results discussed here. However for the Ur excavation site multi-element analysis was performed on 25 samples dating to the EDIII and the Akkadian period. The arsenic and tin concentrations of these samples are shown in Fig. 7, which demonstrates that Ur alloys have a similar major composition to the arsenical bronze and tine alloys from other Mesopotamian sites. Also in this case the minor constituents indicate a different provenance of the bronzes. In contrast to the northern part of Mesopotamia where the use of tin bronzes was temporarily stopped during the Akkadian period, results show that in Ur tin bronzes were continuously available during this period. The latter means that the southern part of Mesopotamia kept continuously access to tin sources. Moreover, the major part of the tin bronzes contains an intermediate concentration of tin (about $8 \mathrm{wt} . \%$ ), which again is different from the northern part of Mesopotamia 


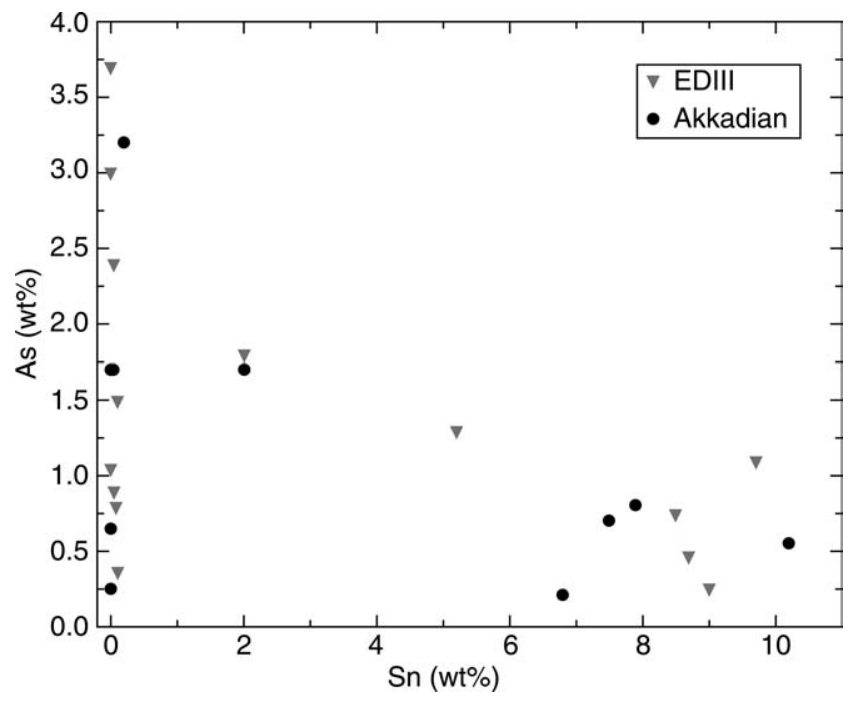

Fig. 7. Scatter plot of the arsenic vs. tin content for the samples from Ur (data from [11]).

where also an important number of low-tin content bronzes is present.

\subsection{The Iranian plateau}

Bronzes originating from sites located on the Iranian plateau were analysed by Thornton et al. [24] (100 samples all of them originating from Tepe Yahyah) and Vatandoust (170 samples the major part originating from the archaeological sites of Shadad, Marlik, Bookan, Luristan and from unspecified sites south and southwest of the Caspian Sea) [25]. A number of these are dated to the 3rd millennium BC; others are of a more recent date. The arsenic and tin concentration of the bronzes from the $3 \mathrm{rd}$ and $2 \mathrm{nd}$ millennium $\mathrm{BC}$ is shown in Fig. 8. Arsenic concentrations range up to 6.8 wt. $\%$. Furthermore, the bronzes of this period show a low concentration of antimony, while the nickel concentration does not

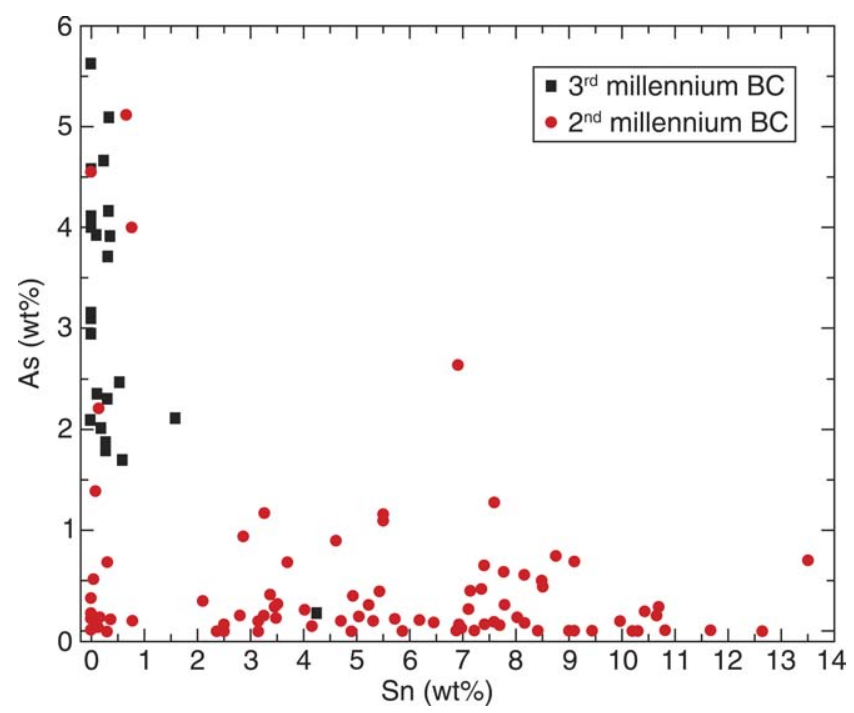

Fig. 8. Scatter plot of the arsenic vs. tin content for the samples from the Iranian plateau (data from [24,25]). exceed 0.3 wt. $\%$. The first tin bronzes occur at the beginning of the 2nd millennium BC.

The use of tin bronzes at the Iranian plateau seems to start about 500 years later than in Mesopotamia. One explanation could be that at the Iranian plateau, there was no direct access to tin sources until the 2nd millennium BC. This observation is important for discussions on the origins of tin bronzes where Afghanistan, neighbouring the Iranian plateau, is frequently mentioned as a likely source of tin. In case Afghanistan was a major source of tin in the 3rd millennium BC, at least some tin bronzes should have been recovered from the Iranian plateau as trade routes pass nearby.

\subsection{Anatolia}

For the Anatolian region little compositional results are available in the literature. According to Yener [16], bronze production in Anatolia (both arsenical and tin) developed into an important industry during the period 3400-2900 BC, which is earlier than the start of production of tin bronze in Mesopotamia. This is confirmed by the recovery of 140 metallurgical artefacts (bronze objects, charcoal and crucibles) at Amuq, an archaeological site in Anatolia. Twenty of these objects were analysed by Braidwood et al. [26]. Amongst the analysed objects two bronze figurines, a male and a female dating to the beginning of the $3 \mathrm{rd}$ millennium $\mathrm{BC}$, show a tin concentration of 7.4 and 10.9 wt. $\%$.

A possible source of tin is the Kestel mine located in the Taurus mountains (Turkey) [16]. An ancient production site, Göltepe, was found near the mine and has been dated to the Early Bronze Age (4350-1978 BC). Some of the vessels recovered from the site are considered to be crucibles in which tin from the Kestel mine was smelted [27]. In a study of such a crucible fragment by Adriaens [15], this point of view is confirmed by the presence of a layer corresponding to a composition and a structure typical to that of tin slag. There is doubt that this mine could have been providing the entire Near East with tin, but it must have played a role in the discovery of tin bronzes since tin bronzes were first occurring in Anatolia. It is possible that later when the mine was depleted or discontinued for other (political, economic) reasons, other sources of tin were used for the bronze production.

\section{Conclusions}

The compositional variation of bronze alloys, dating to the 3rd millennium BC, excavated at various Mesopotamian archaeological sites is quite similar. At the end of the 4th and at the beginning of the 3rd millennium BC copper arsenic alloys with an arsenic concentration up to $5 \mathrm{wt}$.\% were generally applied. Tin bronzes were introduced during the middle of the 3rd millennium BC (EDIII, 2600-2300 BC). This introduction appears almost synchronously over the entire region of Mesopotamia, although there is an indication that the tin bronze introduction was slightly later in southern Mesopota- 
mia. The concentration of tin ranges between low ( 2 wt.\%) to high (> $10 \mathrm{wt} . \%$ ) contents. Only for the Carchemish region high tin content bronzes were not discovered. During the Akkadian period in the Jezireh region (northern Mesopotamia) the use of tin bronzes ceased, which could possibly mean that the Akkadian oppressors at this moment had no access to tin sources, but afterwards tin bronzes reoccur. In contrast, tin bronzes were continuously used in the southern cities (Susa, Ur) of Mesopotamia.

During the 3rd millennium BC bronze was also recycled. Especially the bronzes of Tell Beydar dating to the EDIII period show evidence of this, indicated by a low concentration of tin in the arsenic bronzes. Similar observations were made for different other Mesopotamian sites. At Susa the tin concentration in the arsenical bronzes increases simultaneously with the increased use of tin bronzes, an indication that tin enters the arsenical bronzes by using tin containing metal scrap.

Next to the differences in concentration of the major constituents ( $\mathrm{Cu}, \mathrm{As}$ and $\mathrm{Sn}$ ), the concentration of the minor elements is prone to variation. The nickel concentration is variable, indicating a possible difference in provenance of the metals. In particular for the Carchemish region at least three different origins are possible on the basis of the nickel concentration, whereas for the Jezireh only two different origins can be identified. Nevertheless, the elucidation of the provenance of the metals remains precluded by the likelihood of metal recycling and the addition of alloying elements. Furthermore, to obtain more precise provenance information, more systematic accurate trace and/or lead isotope analysis should be conducted.

A remaining point of discussion in the literature is the origin of the tin used for the production of tin bronzes in Mesopotamia. Recently published results indicate that the first discovery of tin bronze technology should be situated in the Taurus mountains (Kestel mine) in Anatolia [16,24]. The most ancient tin bronzes, dating to the end of the 4th, beginning of the 3rd millennium BC appear at Mesopotamian sites about 500 years later. On the Iranian plateau the first tin bronzes appear in the 2nd millennium BC, about 500 years after Mesopotamia and about one millennium after the introduction in Anatolia. On the basis of this Afghanistan, neighbouring the Iranian plateau, can be excluded as the first source of tin in Anatolia or northern Mesopotamia, since tin bronzes were not recovered in Iran, although trade routes must have passed by. However, Afghanistan remains a possible tin source for the 2nd millennium BC, since it is believed that the mines in the Taurus mountains were unable to supply sufficient tin for the Mesopotamian bronze production.

\section{Acknowledgements}

The authors would like to thank P. Northover for kindly providing his data on Tell Brak, Tell Mozan and Tell Leilan.

\section{References}

[1] D.A. Scott, Copper and Bronze in Art: Corrosion, Colourants, Conservation, The Getty Conservation Institute, Los Angeles, 2002.

[2] R.F. Tylecote, A History of Metallurgy, second ed, The Institute of Materials, London, 1992.

[3] P.T. Craddock, Early Metal Mining and Production, Edinburgh University Press, Edinburgh, 1995.

[4] R. Maddin, T. Stech Wheeler, J.D. Muhly, Distinguishing Artifacts Made of Native Copper, J. Archaeol. Sci. 7 (1980) 211-225.

[5] G. Rapp Jr., Determining the origins of sulfide smelting, in: A. Hauptmann, E. Pernicka, G.A. Wagner (Eds.), Old World Archaeometallurgy, Proceedings of the International Symposium "Old World Archaeometallurgy" Heidelberg, Dt. Bergbau-Museum, Bochum, 1987, pp. 107-110 (1989).

[6] D.T. Potts, Mesopotamian Civilization, The Material Foundations, The Athlone press, London, 1997.

[7] J.D. Muhly, Copper and tin: the distribution of mineral resources and the nature of the metals trade in the bronze age, in: Hamden Transactions of the Connecticut Academy of Arts and Sciences 46, 1973, pp. 77-163.

[8] H. Lechtman, S. Klein, The production of copper-arsenic alloys, (arsenic bronze) by cosmelting: modern experiment, ancient practice, J. Archaeol. Sci. 26 (1999) 497-526.

[9] H. Lechtman, Arsenic bronze: dirty copper or chosen alloy? A view from the Americas, J. Field Archaeol. 23 (1996) 477-514.

[10] P.R.S. Moorey, Ancient Mesopotamian Material and Industries: The Archaeological Evidence, Oxford University Press, Oxford, 1994.

[11] P.R.S. Moorey, Materials and Manufacture in Ancient Mesopotamia: The Evidence of Archaeology and Art; Metals and Metalwork, Glazed Materials and Glass, B.A.R., Oxford, 1985.

[12] S. Cleuziou, T. Berthoud, Early tin in the near east: a reassessment in the light of new evidence from Western Afghanistan, Expedition 25 (1982) 14-19.

[13] P. Northover, Analysis of bronze age metalwork from Tell Beydar, in: K. Van Lerberghe, G. Voet (Eds.), Tell Beydar: Environmental and Technical Studies, Subartu VI, Brepols, Turnhout, 2000, pp. 117-123.

[14] K.A. Yener, H. Özbal, E. Kaptan, A.N. Pehlivan, M. Goodway, Kestel: an early bronze age source of tin ore in the Taurus mountains, Turkey, Science 244 (1989) 200-203.

[15] A. Adriaens, Elemental composition and microstructure of early bronze age and medieval tin slags, Mikrochim. Acta 124 (1996) 89-98.

[16] K.A. Yener, The Domestication of Metals: The Rise of Complex Metal Industries in Anatolia, Brill, Leiden, 2000.

[17] A. Bossuyt, L. Broze, V. Ginsburgh, On invisible trade relations between Mesopotamian cities during the third millennium BC, Prof. Geogr. 5 (3) (2001) 374-383.

[18] I. De Ryck, A. Adriaens, F. Adams, Microanalytical metal technology study of ancient near eastern bronzes from Tell Beydar, Archaeometry 45 (4) (2003) 579-590.

[19] P. Northover, Analysis of the metalwork from Tell Brak, in: D. Oats, J. Oats, H. McDonald (Eds.), Excavations at Tell Brak; vol. 2: Nagar in the Third Millennium BC, McDonald Institute Monographs, 2002, pp. 254-256.

[20] Northover, personal communication, 1999.

[21] P. Northover, Analysis of Bronze Age Metalwork from Tell Mozan, Tell Leilan and the Carchemish Region, unpublished.

[22] F. Tallon, J.-M. Malfoy, Métallurgie Susienne I: 1. De la fondation de Suse au XVIII ${ }^{\mathrm{e}}$ avant J.-C, Paris: Notes et documents des musées de France, Paris, 1987. 
[23] J.M. Malfoy, M. Menu, La Métallurgie du cuivre à Suse aux IV et IIIe Millénaires: Analyses en Laboratoire, in: F. Tallon, J.-M. Malfoy (Eds.), Métallurgie Susienne I: 1. De la fondation de Suse au XVIII ${ }^{\mathrm{e}}$ avant J.-C, Paris: Notes et documents des musées de France, Paris, 1987.

[24] C.P. Thornton, C.C. Lamberg-Karlovsky, M. Liezers, S.M.M. Young, On pins and needles: tracing the evolution of copper-base alloying at Tepe Yahya, Iran, via ICP-MS analysis of common-place items, J. Archaeol. Sci. 29 (2002) 1451-1460.
[25] A. Vatandoust, A view on prehistoric iranian metalworking: elemental analyses and metallographic examinations, in: A. Hauptmann, E. Pernicka, T. Rehren, Ü. Yalçin (Eds.), The Beginnings of Metallurgy, Der Anschnitt, Bochum, 1999, pp. 121-140.

[26] R.J. Braidwood, J. Burke, N.H. Nachtrieb, Ancient Syrian coppers and bronzes, J. Chem. Educ. 28 (1951) 87-96.

[27] A. Adriaens, K.A. Yener, F. Adams, An analytical study using electron and ion microscopy of thin-walled crucibles from Göltepe, Turkey, J. Archaeol. Sci. 26 (1999) 1069-1073. 